\section{Health and innovation: economic dynamics and Welfare State in Brazil}

\author{
Saúde e inovação: dinâmica econômica e \\ Estado de Bem-Estar Social no Brasil
}

\author{
Salud e innovación: dinámica económica y \\ Estado de Bienestar Social en Brasil
}

Carlos Augusto Grabois Gadelha 1

Patrícia Seixas da Costa Braga 2

\begin{abstract}
The effective enforcement of the access to healthcare as fundamental right requires an important theoretical and political effort at linking the often contradictory economic and social dimensions of development. This study suggests the need for a systemic view of policies related to the industrial base and innovation in health and the construction of the Brazilian Unified National Health System (SUS). The authors investigate the relations between health, innovation, and development, seeking to show and update the political, economic, and social determinants of the recent Brazilian experience with the Health Economic-Industrial Complex (HEIC). They discuss how the agenda for innovation and domestic industrial production in health gained a central place in the project for construction of the SUS. The article thus seeks to link inherent issues from the agenda for development, production, and innovation to social policy in healthcare, as observed in recent years, and based on this analysis, points to political and conceptual challenges for implementing the SUS, especially as regards strengthening its technological and industrial base. As a byproduct, the article develops an analytical and factual focus on the consolidation of the HEIC in Brazil, both as a dynamic vector of industrial development, generating investment, income, employment, and innovations, and as a decisive element for reducing vulnerability and structural dependence in health. The authors aim to show that strengthening the SUS and orienting it to social needs is an essential part of building a social Welfare State in Brazil.
\end{abstract}

National Science, Technology and Innovation Policy; Biomedical Technology; Public Policy; Sustainable Development; Innovation

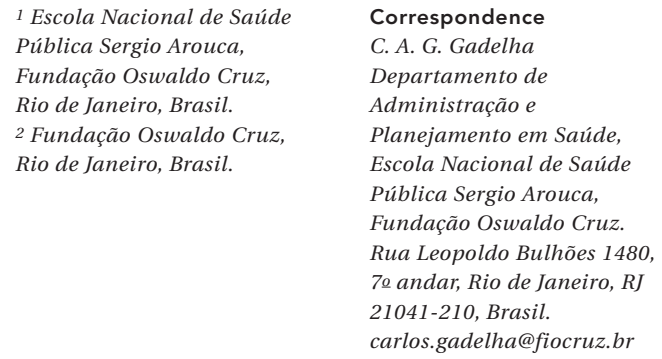

${ }_{1}^{1}$ Escola Nacional de Saúde Pública Sergio Arouca, Fundação Oswaldo Cruz, Rio de Janeiro, Brasil. 2 Fundação Oswaldo Cruz, Rio de Janeiro, Brasil.

\author{
Correspondence \\ C. A. G. Gadelha \\ Departamento de \\ Administração e \\ Planejamento em Saúde \\ Escola Nacional de Saúde \\ Pública Sergio Arouca, \\ Fundação Oswaldo Cruz. \\ Rua Leopoldo Bulhões 1480, \\ 7 a andar, Rio de Janeiro, $R J$ \\ 21041-210, Brasil.
} carlos.gadelha@fiocruz.br 


\section{Introduction}

The enactment of Brazil's Federal Constitution of 1988 crowned the Sanitary Reform movement, part of the country's struggle for re-democratization in the 1980s, by including health in the set of social rights guaranteed as indispensable for the full exercise of citizenship. The new Constitution guaranteed the healthcare as a "right of all" - with universal, comprehensive, and equitable access - and as a "duty of the State" - to be ensured through the adoption of social and economic policies.

The relationship between health and development is not limited to its social nature. It is also important as an economic good and an area for the accumulation and circulation of capital, intensive in critical technologies for the future, with an outstanding role in country's job creation and income generation. Besides that, health is located in a production chain that involves activities in both secondary and tertiary sectors of the economy in the Health Economic-Industrial Complex (HEIC) - an interdependent system that includes a network of knowledge with the convergence of the pharmaceutical, diagnostic, equipment, and materials industries towards health services providers (influencing them and being influenced by them) 1 .

So, since the conception of a universal healthcare system in Brazil, the need for a systemic look at the policies adopted was recognized. However, its real implementation faced a historically tense economic, social, and political environment marked by the full hegemony of neoliberal thinking since the 1990s - which conditioned the planning and adoption of options for action.

Despite efforts and progress since then, through this agenda's appropriation in the sphere of national policies, a bet on the late construction of a Welfare State in Brazil is only feasible through the conjunction of social rights and the establishment of an industrial and technological structure that treats health as a strategic area for national development. This was the conceptual economic policy basis for the concept of the HEIC, formulated in the early 2000s 2, and whose current developments need to be constantly problematized and updated, not only as a theoretical exercise, but fundamentally as essential to a transformative approach that actually integrates the economic and social dimensions of health.

Based on the recognition of the intrinsic relations between health, development, and social welfare, this article begins by addressing the generation of innovations in the health sector, considering their characteristics and their economic, political, and social determinants. Next, the article focuses on the consolidation, in Brazil, of healthcare as a universal right and the understanding of its deep interrelations with national development. Based on the perception of the socioeconomic context, the article seeks to elucidate some critical limiting factors that need to be addressed in order to effectively ensure the right to healthcare. Then identifies the public policies, strategies, and measures that have been adopted to deal with these issues. Finally, it seeks to identify the challenges for the health innovation agenda in Brazil related to the construction of a universal healthcare system.

\section{Comments on the relations between innovation in health and social welfare}

The health productive system is known to be innovation-intensive. The system includes highly complex and dynamic sectors, like modern biotechnology and life sciences (e.g., gene and cell therapy), advanced chemistry, nanotechnology, new materials, microelectronics, and information technology which have a structuring impact on the dynamics of national development However, the generation of innovations is not a socially neutral process 3 , and the definition of technological paths is conditioned by the global industrial and competitive structure, whose dynamics is not necessarily oriented towards social demands. In this scenario, the State plays an indispensable role in inducing and linking the diverse interests that impact the generation of new technologies, giving a direction to the intrinsic objectives of a universal health system and Welfare State.

However, the activities involved in search, generation, and diffusion of innovations in the health sector are conditioned by the competitive strategies of a small group of leading global companies, whose decision-making core is limited to a few countries. Thus, only a limited number of nations effectively participate in and influence these processes. Consequently, the resulting technology pattern is oriented towards meeting health demands based on a global consumption pattern, with growing segmentation both within the developed countries and in international relations. This favors the intensification of the polarity between less and more developed countries and shapes the process of modernization and marginalization cited by Furtado 4 , marked by the progressive exclusion of significant segments of society.

This scenario's effects include the so-called neglected diseases, which receive insufficient funding for the development of adequate 
preventive and therapeutic measures, since they are not economically attractive. In addition, technological dependence denotes difficult access to certain treatments, e.g., for cancer and rare diseases, which require biotech products the access to which is virtually impeded, both in private and public systems, by the high costs. It is thus more appropriate to consider neglected populations and territories, which still occur as the result of a broader economic and social situation (caused by the exchange rate and other international relations, among other factors) 1 .

The discussions and measures for dealing which such issues are not limited to the less developed countries, since they also have strong international repercussions. The United Nations post-2015 development agenda reaffirmed the fight against neglected diseases as one of its priorities, originally one of the Millennium Development Goals on the agenda for 2000-2015, by including it as one of the goals in the proposal now under discussion. Furthermore, the question of access to high-cost treatment with frontier technology demands to consider structural factors for universal, quitable, comprehensive and quality healthcare consolidation, which require the adoptation of the evidence-based technology incorporation practices in order to be sustainable.

The means to achieve this objective are not limited to supporting research and innovation in the necessary products for fighting diseases that mainly affect low and middle-income countries (Buss P. Saúde na agenda do desenvolvimento pós-2015. Personal communication). They also include activities that shape a technological standard without which the universal and comprehensive access becomes unattainable even for diseases that affect diverse groups of countries with different levels of development.

\section{Inherent issues in the Brazilian health sector development agenda}

In Brazil, the political side of the right to universal, comprehensive and equitable access to healthcare associated with demographic and epidemiological changes - related to population aging and the growing proportion of chronic non-communicable diseases in the overall health and disease profile - and as well as underfunding of the proposed universal system are identified as the main problems for the state. The growing demand for goods, services, and incorporation of technologies by the healthcare system indicate some trends and impact points in the health industrial base.
Implementation of the Brazilian Unified National Health System (SUS) failed to fully grasp the complexity of the fact that the universal healthcare system consisted of a series of organizations responsible for supplying necessary health technologies, inputs, and products such as: medicines, drugs, immunobiologicals, equipment, diagnostic technologies, and even the health services that constitute the space for realization of capital and generation and diffusion of innovations 5 .

In fact, the prevailing economic and political context was unfavorable. The fiscal crisis of the early 1990s and adoption of neoliberal ideals ended up distancing the State from Brazil's national industrial agenda. What happened was "regressive specialization" of Brazilian industry, with the loss of competitiveness in the installed health industrial park 6,7. Specifically for the health sector, the pro-competition structural reforms inherent to the economic opening launched at the time particularly featured the impacts of the early adjustment (already in 1996) of Brazil's legislation on industrial property, beyond the minimum dictates of the World Trade Organization, the effects of which on industry further aggravated the process of its dismantling in that decade.

Thus, the increasing demand for health services resulting from implementation of the SUS coincided with the adoption of a liberal political model that distanced the State from its role as inducer and mediator of the interests involved in production in health 8 . This explains the weakness of the knowledge and industrial base, which was inconsistent with demand and failed to develop with a true focus on the population's health interests 9 .

Brazil's vulnerability and structural dependence in ensuring the right of access to healthcare services are expressed in the burgeoning trade deficit in the health industrial system - quadrupled in real terms from 2003 to 2013, reaching US\$ 12 billion in 2013 - and in the growing gap between the research potential and generation of innovation when compared to the developed countries. Concerning the latter, data from the pharmaceutical industry reveal the gap between the investment pattern in research and development (R\&D) by large multinational corporations and the Brazilian industry: despite a significant increase in internal investment in $R \& D$, from $0.83 \%$ of total net sales in 2000 to $2.39 \%$ in 2011, Brazil's industry still falls far short of the benchmark set by global Pharma (around 15$20 \%$ ). And given the relevant presence of these international companies in the Brazilian market, their investment in internal $R \& D$ activities is still small, since they concentrate their research 
efforts in their home countries 10,11,12. Such circumstances highlight the need to strengthen the HEIC, which involves inducing its productivity, adjusting the regulatory framework, and linkage, by the State, of the health sector's economic and social dynamics.

In fact, health becomes one of the pillars of the Welfare State and qualifies as a critical industrial system for the contemporary dynamics of production and innovation, since its activities are knowledge-intensive and produce an important share of the global wealth. Considering the size of the Brazilian population and market, national development strategies can simultaneously bolster the industrial activities and orient the supply structure according to the social demand for health 13 .

In this context, to overcome dependence and a mismatched technological standard (which is inconsistent with the universal, comprehensive, and equitable care demanded by the Brazilian population) requires building national policies and the State's strategic capability for dealing with major inter-sector challenges 14 .

From this perspective, the HEIC concept relates to the need for a systemic approach to health, which implies an analytical effort that encompasses the interdependent dynamics of the different industrial subsystems, which are organically interconnected, although heterogeneous. This also denotes the challenging task of linking the specific technological and sectorial dimensions to comprehensive issues of political economics that relate to the issue of the State's capacity and degrees of freedom to establish universal health policies, defining the very limits of sovereignty in health.

In this scenario, the domestic business sector's limited participation in more radical innovations reveals Brazil's vulnerability, while it allows defining some of the priority scientific areas for innovation, especially biotechnology, advanced chemistry, new materials, microelectronics-related medical and hospital equipment, as well the growing convergence and integration of information technologies and life sciences technologies $15,16,17$.

The national strengthening of scientific, technological, and productive capabilities in the health sector industries, plus their global linkage, require systemic measures that extend beyond the supply of $R \& D$ infrastructures to include the selection of areas oriented by a policy of universal and comprehensive access, a strategy for human resources, financing, and the market to effectively involve the business sector, with the State as a key player in the orientation of innovation and investment efforts.
In universal systems, where State health policies play a decisive role in setting the pace and defining the technological paths, economic logic can be adjusted or at least challenged by social logic, placing limits on the abusive and irrational use of new technologies, while creating new spaces for innovation and investments linked to sustainable demand with greater health rationality. Such linkage allows moving towards effective universality, at least in the experience of some Organisation for Economic Co-operation and Development (OECD) countries in the postwar period 18 . These cases displayed innovation policies with the adoption of such instruments as government purchases, financing, regulation, and consumption policies influenced by users, as well as "pilot markets", thereby seeking a standard of interaction with the market in areas with pressing social needs, which denotes acknowledgment of the importance of interactions and feedbacks between supply and demand in innovation processes 19,20.

From another angle - considering the possibility of building a political and economic support base, instead of the welfare state being viewed as an obstacle to development - health can provide an excellent example of the possibility, in the 21st century, of resuming the postwar perspective that simultaneously allied the economic and social dimensions of development (especially in the European experience). Universal healthcare systems may be seen driving force for generating income and employment, investiments and technologies, which are clear sources of dynamism and economic expansion. Meanwhile, in Brazil's experience, health can be a decisive element of social cohesion to allow a political base for development, without which development would be impossible.

This emphasizes the growing importance of the public policies adopted by the Brazilian State for the effective implementation of the universal and equitable healthcare system as provided by the 1988 Constitution. Such policies need to bring to the social field the logic of capital, not subordinated to it, but due to the need to acknowledge the relations established with productive forces. This would require reinforcing the roles of the State and civil society, not to deny capital or the prevailing mode of production, but to orient, interact with, and regulate its movement, seeking virtuous circuits and a social base of political support. 


\section{Policies for strengthening the HEIC in Brazil}

Acknowledgement of the intrinsic relationship between the field of health and development in Brazil provided the basis for the public policies designed in the 2000s, facing the perceived need for development of the industrial base in health and its capacity to generate innovations, without which various knowledge-intensive programs would be jeopardized, including the National Immunization Program and programs in oncology, AIDS, and cardiology, among others. These policies also acknowledged the major challenge of promoting the inclusion of Brazil's national health industry in the global economy 21 , since it was suffering loss of competitiveness and denationalization, especially in the most technologyintensive products 8,22 .

This acknowledgement sparked the resumption of industrial policy measures in the area. In 2003, the country launched the Industrial, Technological, and Foreign Trade Policy (PITCE), representing the resumption of two central issues on the current macro policy agenda: the defense of a necessary industrial policy and the importance of selecting strategic sectors for fomenting national development, including health 23 .

Subsequently, a set of policies were drafted that were oriented specifically to health. In 2004, the Brazilian National Policy for Science, Technology, and Innovation in Health was approved, being implemented more systematically from 2007. Also in 2007, the "More Health" Program defined the health complex as one of the strategic health policy areas, with a proposed three-year budget of BRL 2 billion to reduce the health sector's trade deficit 24 . In 2008, the Industrial Development Policy defined the health complex as one of the six strategic future-bearing areas.

Also in 2007, the Action Plan for Science, Technology, and Innovation, 2007-2010, of the Ministry of Science and Technology, under the heading "health inputs", designated health as one of its strategic areas, orienting the financing and action of the Brazilian National System of Science, Technology, and Innovation.

The "Greater Brazil" Plan, launched in 2011, gave further impetus to the PITCE and to the policies mentioned in regard to health in health. In addition to reaffirming health's leading role as a priority area in government policies, it set guidelines and major concrete measures to intensify industrial development partnerships and utilization of the government purchasing power resulting in the construction of the SUS.

The Executive Group of the Health Economic-Industrial Complex (GECIS), created at the time of the establishment of the Industrial Development Policy 25, was thus reaffirmed as an inter-ministerial coordinating body and with participation by the industrial sector and civil society, including representative segments of the National Healthcare Policy, who gradually began to increase their participation in this project (Brazilian National Council of Health Secretaries - CONASS, Brazilian National Council of Municipal Health - Conasems, and Brazilian Association of Public Health - Abrasco, for example). This linkage between health policy and industrial policy acted as an unprecedented factor in contemporary Brazilian history, allowing a reclaiming of the constitutional perspective of convergence between economic and social policies.

Finally, the priority of the pharmaceutical sector and the health industrial complex was reaffirmed by the Brazilian National Strategy for Science, Technology, and Innovation launched in 2012, emphasizing the promotion of mechanisms to stimulate innovation in health and the intensification of technology transfer to government laboratories, while identifying a series of gaps that need to be resolved in the Brazilian industrial base.

The policies aimed to close the technology gap, foment domestic industry's competitiveness, and reduce the public deficit resulting from inputs for the health sector. The strategies included a set of measures featuring the use of government purchases, promotion of financing and fomenting the health sector industries, and strengthening a network of cuttingedge institutions.

Government purchasing power is also widely used by developed countries in strategic areas like defense - for example, U.S. defense policy, which pushed all of microelectronics and the country's competitiveness, under the mantle of national security -, with initiatives linked to innovation in health, featuring European policies to promote technological capability 17,26 . In Brazil, health security was placed on the same level as defense (or even higher), which was unprecedented even in the international experience and revealed an essential dimension for guaranteeing constitutional rights in a universal system, in a continental-sized and profoundly unequal country 6 .

In addition, one of the watersheds of Brazilian policy was the search for internalization of production of health products in the country (medicines and drugs, equipment and materials, vaccines and diagnostics), through partnerships for industrial development (PDPs) among public producers and domestic and foreign private companies. The initial milestones for this 
initiative were: the Program for Self-Sufficiency in Immunobiologicals (PASNI) of 1985 which responded to a supply crisis by focusing on the need for domestic production through technology transfers from large pharmaceutical companies to government institutions (featuring Oswaldo Cruz Foundation - Fiocruz and Butantan Institute); Inter-Ministerial Ruling 128/2008, which established the guidelines for bidding on drugs and medicines by the SUS, involving partnership between government institutions and private pharmaceutical manufacturers; and Ministry of Health Ruling 978/2008 (updated and expanded by Ruling 3,089/2013), determining the list of strategic products for the SUS.

This initiative gained scale beginning 2011, possibly representing the most ambitious policy for enforcement of the constitutional principles that the market is part of the national endowment, that scientific and technological development should be stimulated by the State, and that health is a right for which national technological capability is an essential condition. This fact demanded the expansion of the health legal framework to provide it with a consistent institutional base.

Therefore, in 2012, the Ministry of Health issued Ruling 837, establishing the first steps in the political formalization of defining guidelines and criteria for the PDP, with the subsequent enactment of Law 12,715 on September 18, 2012. This law made unprecedented changes to national innovation policy by introducing amendments to the prevailing Law on Bidding and Administrative Contracts (Law 8,666/1993): removed the time limit for qualifying public producers as the receivers of direct commissions - previously applied only to producers created prior to 1994 -, thus expanding the list of public institutions and institutes of science, technology, and innovation in health for meeting this type of demand (article 24 , section 2); and effectively allowed the largescale use of government purchasing power to induce transfer of strategic technologies to the SUS (article 24, XXXII).

Transfer of the technologies in question firmly established the healthcare system's use of reverse engineering procedures (or reverse biotechnology) utilized in industrial policy experiments in East Asia (with Japan and South Korea as outstanding examples of globally important countries), which allowed introducing products on the market through technology transfers, leapfrogging to access and incorporate technologies at affordable prices for the State. The scale of the SUS and of the Brazilian market simultaneously allowed price reductions (e.g., the recent vaccines for HPV at about one-tenth the price charged by private clinics) and the acquisition of critical technological platforms for public health activities.

At the end of 2014, according to the Secretariat for Science, Technology, and Strategic Products of the Ministry pf Health, there were 103 productive and technological development partnerships - 19 estabilished with piblic institutions and 55 private companies, domestic and foreign - with 33 products in already registrated at Brazilian Health Regulatory Agency (Anvisa), of which 26 where at the time, acquired by Ministry of Health 27.

In addition, the policy of using purchasing power also involved right of preference for domestic producers in government purchases. Law 12,349/2010 amended Law 8,666/1993 to include sustainable national development as one of the objectives of the bidding procedures. It therefore set a margin of preference in government purchases, favoring domestic producers by up to $25 \%$, considering that the price of the product to be supplied now considered aspects such as generation of employment and income, impact on tax revenues, and other factors. Technological "off set" was also introduced, featuring the purchase of equipment for radiotherapy, with the function of assessing the possibility of purchases whose criterion for analyses included technological development interests 1 .

Another development was support for production by public institutions - aimed at supplying medicines, vaccines, diagnostic reagents, biopharmaceuticals, and more recently the potential manufacturers of medical equipment, devices, and materials, in the context of the Program for Investment in the Health Industrial Complex (PROCIS/2012). The budget resources invested in this area alone increased some fivefold from 2011 to 2014, with some BRL 1 billion earmarked as funds in grant to make the public arm of the partnerships capable of absorbing and developing the priority technologies for the SUS.

The promotion of financing features a set of measures adopted by the Federal Government in recent years, especially the creation of funds in the health and biotechnology sectors, CT-Health and CT-Biotechnology, the Program for Economic Subvention, the Inova-Enterprise Plan, and the Program to Support the Development of the Pharmaceutical Industrial Chain (Profarma).

CT-Health and CT-Biotechnology, created by Law 10,332/2001, combine the set of Science and Technology Sector Funds, the purpose of which is to cover the cost of projects in research, development, and innovation in the country, an important instrument of the Federal Government to leverage the Brazilian Science, Technol- 
ogy, and Innovation System. CT-Health aims to stimulate technological capability in relevant areas for the SUS (public health, pharmaceuticals, biotechnology, etc.), augment private investments in $R \& D$, promote technological updating of the Brazilian medical and hospital equipment industry, disseminating new technologies that expand the population's access to goods and services in health; and CT-Biotechnology with the aim of training and qualifying human resources; strengthening the national infrastructure in research and support services; expand the area's knowledge base; stimulate the formation of companies with a biotechnology base and technology transfer to consolidated companies; conduct prospecting studies and monitoring progress in knowledge in the sector 28 . The resources from these funds are disbursed by the Funding Authority for Studies and Research (Finep) and the National Council for Scientific and Technological Development (CNPq).

The Program for Economic Subvention, created in 2006 and coordinated by Finep, established a unique form of support for domestic companies, earmarking funds in grant for the business sector. This program's focus is to support innovative projects and not companies' innovation strategies, which was compromised, since the perspective of including the results on the market was not written into many of the calls for projects 29 .

More recently, in March 2013, the Inova-Enterprise Plan was launched, with Finep and the BNDES (the Brazilian National Economic and Social Development Bank) as the key financial arms, with the purpose of supporting the increase in the economy's productivity. This plan included an innovative governance mechanism, with strong linkage of ministries, agencies, and other institutions, as an effort to build technology policies on a higher level, and divided into programs, one of which devoted specifically to health, the Inova Health Program: an initiative by the Ministry of Science, Technology, and Innovation and Finep, in cooperation with the Ministry of Health, BNDES, and CNPq. Its creation aimed to support resaerch, development and innovation (RD\&I) activities in projects in public and private institutions working in the strengthening of the HEIC and provides for BRL 3.6 billion in investment on innovation activities in the Health Complex by December 2017 6,30.

Profarma (Program to Support the Development of the Pharmaceutical Industrial Chain), another important program of innovation funding for the pharmaceutical sector, was established in 2004 by the BNDES as an instrument of the PITCE. The first stage aimed to adjust the do- mestic industrial plants to good manufacturing practices, expansion of the production capacity, and initial support for investments in technological innovation in the industry. The year 2007 marked the program's first renewal, focusing on the challenge of promoting more systematic investment in innovation by domestic industry. The program entered its third stage in 2013, with the goal of establishing a long-term policy for the Health Industrial Complex, emphasizing the pharmaceutical industry and innovation, and with a budget of BRL 5 billion by 201731 .

However, the implementation of these actions is experiencing various types of problems, especially the allocation of originally budgeted funds and the lack of qualified innovation projects 32 , inherent to the process of institutional learning in a new age and in a new intervention modality and the gaps in institutions working with production and innovation in health in a heavily dependent country.

The strategy for strengthening a network of leading institutions aims to allow an approach between the social dimension of innovation and the field of healthcare. Part of the perception that the establishment of an endogenous innovation base oriented towards meeting the demand by services requires a network of institutions that serve as the anchor for the national development strategy. This assumes the consolidation of leading knowledge-intensive institutions, including in the services sector, capable of establishing dynamic networks with the industrial sector 19. However, despite the growing relevance of healthcare services in the formation of GDP and income, the initiatives thus far aim more directly at dealing with the need to overcome the domestic industry's gap.

Following initial implementation of policies for strengthening the HEIC, it was not until 2014 that a drop in the trade deficit in health was finally observed, as shown in Figure 1, even with the continuing expansion of all the health markets 1 . It is still too early for an in-depth analysis of when this movement will reflect a new trend, but one should highlight the structural role of the trade deficit in health, more compromised by technological dependence than by changes in relative prices and the currency exchange rate, as has been extensively discussed 33 .

Corroborating this view, Figure 1 also shows that even in periods of exchange devaluation, like in the late 1990s, deterioration of the trade balance persisted throughout the years - regardless of the exchange rate and relative prices -, thus revealing this indicator's structural component. More than economic and financial dependence, Brazil suffers a dependence in knowledge and 
Figure 1

Evolution of the Brazilian trade balance in health: overview, 1996-2015.

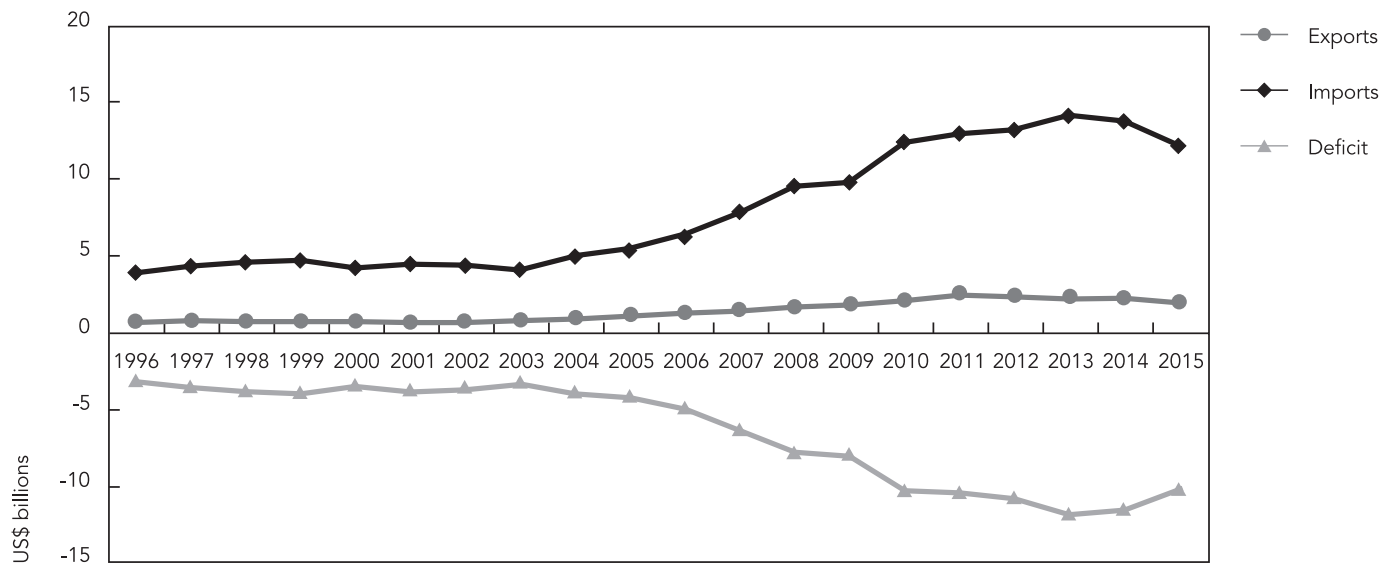

Source: prepared by Research Group on Innovation o Health, Grupo de Pesquisa de Inovação em Saúde, Sergio Arouca National School of Public Health, Oswaldo Cruz Foundation (GIS/Ensp/Fiocruz), from data of Rede Alice (http://aliceweb.mdci.gov.br/menu/index.item/modulosConsulta, accessed on $\operatorname{Jan} / 2016)$.

technologies that cannot be overcome by cyclical price changes. The drop in the trade deficit in 2014 can thus be an important indicator to be evaluated in future historical series of the results of the convergence of the above-mentioned policies.

In a political and economic crisis like Brazil's current crisis, the traditional dilemmas of linking the economic and social dimensions dimensions of development returns to condition the direction of potential strategies for reversing the weakness observed in the HEIC. Still, the increase seen in the last decade, its political and cognitive consolidation (the economic and social logics cannot be separated), and its potential transformation into a State policy, considering the qualitative leap in more recent years, authorize stating that rather than restriction, this experience may become one of the wagers showing the possibility and wealth of a strategy that combines the pursuit of competitiveness with the construction of a Welfare State in Brazil.

For this to happen, the alignment of the health sector with the development agenda requires advancing a State policy that links a decrease in technological dependence, overcoming the low rate of conversion of knowledge to innovation, the weakness of the educational system, asymmetries in access, and inequalities in supply and demand vis-à-vis a policy for technological incorporation that has to be universal, comprehensive and scientifically based.
Final remarks: challenges for the health innovation agenda in Brazil

It is still too early to evaluate the effectiveness and potentialities of the policies Brazil has adopted to foment the social orientation of its national technological development, although the current article illustrates the political substantial change in the area, the institutional efforts and the investiments already made, which already allows a preliminary assessment of the production activities and technologies incorporation in the center of the national health strategy. It is thus possible to identify challenges that still need to be overcome in health in Brazil, which involves achieving a more in-depth understanding of the dynamics of market and capitalist interests in social spaces and how their contradictions can be regulated.

One of the main challenges is to find the means to virtuously link all the components that impact health services' structures and the economic interests associated with them. A universal healthcare system in Brazil also needs to occupy a central position in State policies, seeking solutions to the problem of underfinancing, and especially the public sector's low share in this funding ${ }^{34}$.

Another challenge is to tackle the issues of weakness in the domestic industrial capacity, reflected in the heavy external dependence in 
products for the HEIC (especially the ones with the greatest technological complexity). This results from the lack or insufficiency of the endogenous innovation base, which if not resolved will lead to a "cascade effect" characterized by an increase in Brazilian industry's technology gap, leading in turn to a loss of competitiveness and an inevitable aggravation in the retraction of the domestic industrial park, growing dependence on imports, and an increase in the health sector's inherent cost, rising trading deficit, and finally jeopardizing or impeding public policies to guarantee the universal and equitable right to health acknowledged by the Brazilian State as an inalienable condition for the full exercise of citizenship.

Thus, the measures adopted thus far to strengthen the endogenous innovation base need to be reinforced, especially stimulating its convergence with healthcare needs, which includes: expansion of the process of structuring a network of State institutions to support a nationwide strategy; the adoption of a cross-cutting, interdisciplinary policy involving all spheres of government in order to link the economic interests and oriented them according to social interests, which representative instances of society must be incorporated; strengthening the policy for technology assessment and incorporation, to avoid the health system's incorporation of technologies that are not adequate for its institutional model or for the population's epidemiological profile, besides controlling the growing judicializaton of access healthcare; improvement of the regulatory framework for technological incorporation and the use of State purchasing power; and adjustment of the administrative and incentives model for strengthening the HEIC.

The regulatory framework should contemplate the need to build strategic capability at the federal level of the healthcare system, whose decentralized conception prioritizes taking actions at the State and especially municipal levels - devoted to guaranteeing the predominance of a national vision and organic nature of the actions for the formation of a territorially integrated system. Such measures, aimed at avoiding the fragmentation and resulting systemic inefficiency of actions in health, require the incorporation of a strategic body of professionals in the SUS, capable of elaborating, inducing, and assessing the national policies and dealing with the democratic issue and the mechanism for federative participation in the system.

In addition, one of the premises for health actions to be efficient and integrated is the definition of the welfare model one wishes to implement in the country. Many of the challenges are located in the policy sphere of the SUS, implying the indispensable orientation of technological development according to the needs of the innovation system and the population's social demands in health. This system is expected to be mission-oriented (i.e., to the needs of a universal system), whereby innovations follow socially desirable and sustainable paths, while simultaneously desirable and sustainable vis-à-vis the economic demand for the industrial sector, without which the ideals of citizenship find no material basis for their fulfillment. This requires conceiving the structural sustainability of the Brazilian health system tied to the desired economic and social development standard, as a direction for the State to virtuously link conflicting interests around a social vector (after all, this was the classic role that made the postwar Welfare States possible).

Such challenges have now been overtaken by the political and economic crisis in Brazil, shaping a particularly unfavorable scenario. The persistently low national industrial capacity is further aggravated by the strained exchange rate, such that the incorporation of technologies places a proportionally higher burden on the budget of the SUS. Since the funds are limited, technologies may further replicate the inequalities in the Brazilian system, or on the contrary, serve as an essential basis for universality, equity, and comprehensiveness, a process to be demarcated in the sphere of policy projects that achieve convergence of forces around a given hegemonic position.

If the Brazilian State succeeds in placing priority products for the SUS on the market through partnerships between public institutions and the industrial sector to generate technological opportunities and decrease the country's industrial dependence, the result may be a more favorable situation, linking mass consumption and affordable prices to the structuring of a universal system, considering the current context's complexity. Thus, at the time of resumption of economic growth, it will be possible to extend the strategy of developing the HEIC to adjust the production and the national capacity for innovation to the needs of the SUS and even to those of global health, combining exports and a contribution to health access in international terms.

This wager implies reconsidering the classic industrial policy development standard to adopt a more systemic standard, focused on the main national problems. Health thereby appears both as a beneficiary of this perspective (after all, it is one of the main national challenges) and as an actual public policy "experiment" that endogenously links the various dimensions of devel- 
opment, moving from a compensatory standard to one in which economic and social dynamism provide mutual feedback in a development path.

Finally, in a more conceptual and exploratory dimension, this article attempted to overcome a functionalist view of health, whether as "human capital" or as an element for the exercise of freedom of individual choice, or as an "input" for macroeconomic development 13,35,36,37. From another perspective, the article attempted to understand health both in its ethical dimension, as an essential factor for citizenship, and as an endogenous element inherent to capitalist dynamics, that is, inherent to the process of capital accumulation, generation of employment and income, and innovation, indicating the interdependence between economic dynamics in health and the shaping of a welfare state 13,38,39,40.

\section{Contributors}

C. A. G. Gadelha contributed to the coordination and overall systematization of the article. P. S. C. Braga collaborated writing and revising the article.

\section{References}

1. Gadelha CAG, Costa LS, Bahia L. Reflexões sobre a saúde na agenda contemporânea do desenvolvimento. In: Costa LS, Bahia L, Gadelha CAG, organizadores. Saúde, desenvolvimento e inovação. v. 1. Rio de Janeiro: CEPESC Editora; 2015. p. 43-69.

2. Gadelha CAG. O complexo industrial da saúde e a necessidade de um enfoque dinâmico na economia da saúde. Ciênc Saúde Coletiva 2003; 8:521-35.

3. Tigre PB. Gestão da inovação: a economia da tecnologia do Brasil. Rio de Janeiro: Elsevier; 2006.

4. Furtado C. O capitalismo global. Rio de Janeiro: Editora Paz e Terra; 1998

6. Gadelha CAG. Desenvolvimento, complexo-industrial da saúde e política industrial. Rev Saúde Pública 2006; 40(n.spe.):11-23.

7. Gadelha CAG, Maldonado JMSV, Costa LS. O complexo produtivo da saúde e sua relação com o desenvolvimento: um olhar sobre a dinâmica da inovação em saúde. In: Giovanella L, Escorel S, Lobato LVC, Noronha JC, Carvalho AI, organizadores. Políticas e sistema de saúde no Brasil. 2a Ed. Rio de Janeiro: Editora Fiocruz; 2014. p. 209-37.

8. Mota FB, Cassiolato JE, Gadelha CAG. Articulação da indústria farmacêutica brasileira com o exterior: há evidências de especialização regressiva? Cad Saúde Pública 2012; 28:527-36.

9. Viana ALd'A, Elias P. Saúde e desenvolvimento. Ciênc Saúde Coletiva 2007; 12 Suppl:1765-77.

10. Costa LS. Os serviços de saúde e a dinâmica de inovação do complexo econômico-industrial da saúde. In: Cunha FLAP, Lázaro CP, Pereira EBB, organizadores. Conhecimento, inovação e comunicação em serviços de saúde. Rio de Janeiro: Editora Fiocruz; 2014. p. 83-111. 
11. Vargas AV, Ribeiro LC, Paiva L, Gadelha CAG. A inovação nos segmentos químicos e biotecnológicos da saúde: nichos estratégicos e lacunas. In: Costa LS, Bahia L, Gadelha CAG, organizadores. Saúde desenvolvimento e inovação. v. 2. Rio de Janeiro: CEPESC Editora; 2015. p. 105-38.

12. European Commission. The 2014 EU industrial R\&D investment scoreboard. http://iri.jrc.ec.euro pa.eu/scoreboard14.html (accessed on Mar/2016).

13. Instituto de Brasileiro de Geografia e Estatística. Pesquisa de inovação 2011. Rio de Janeiro: Instituto de Brasileiro de Geografia e Estatística; 2013.

14. Gadelha CAG. Desenvolvimento e saúde: em busca de uma nova utopia. Saúde Debate 2007; 29:327-38.

15. Gadelha CAG, Noronha JC, Pereira TR, organizadores. Brasil Saúde Amanhã: complexo econômico-industrial da saúde. Rio de Janeiro: Editora Fiocruz; in press.

16. Vargas MA. Indústria de base química no Brasil: potencialidades, desafios e nichos estratégicos. In: Gadelha CAG, Noronha JC, Pereira TR, organizadores. Brasil Saúde Amanhã: complexo econômico-industrial da saúde. Rio de Janeiro: Editora Fiocruz; in press.

17. Ribeiro LB, Paiva LB. Base biotecnológica no Brasil: desafios e nichos estratégicos. In: Gadelha CAG, Noronha JC, Pereira TR, organizadores. Brasil Saúde Amanhã: complexo econômico-industrial da saúde. Rio de Janeiro: Editora Fiocruz; in press.

18. Maldonado J, Oliveira EJV. Base mecânica, eletrônica e de materiais. In: Gadelha CAG, Noronha JC, Pereira TR, organizadores. Brasil Saúde Amanhã: complexo econômico-industrial da saúde. Rio de Janeiro: Editora Fiocruz; in press.

19. Costa LS, Bahia L. Notas para compreender a interação entre serviços de saúde e inovação: uma revisão da bibliografia. In: Gadelha CAG, Noronha JC, Pereira TR, organizadores. Brasil Saúde Amanhã: complexo econômico-industrial da saúde. Rio de Janeiro: Editora Fiocruz; in press.

20. Bahia L, Costa L, Gadelha C, Vargas MA. Compras governamentais: as mãos visíveis do Estado para a inovação. In: Costa LS, Bahia L, Gadelha CAG, organizadores. Saúde, desenvolvimento e inovação. v. 1. Rio de Janeiro: CEPESC Editora; 2015. p. 311-44.

21. Padula R, Noronha GS, Mitidieri TL. Complexo econômico-industrial de saúde, segurança e autonomia estratégica: para pensar a inserção do Brasil frente ao mundo. In: Gadelha CAG, Noronha JC, Pereira TR, organizadores. Brasil Saúde Amanhã: complexo econômico-industrial da saúde. Rio de Janeiro: Editora Fiocruz; in press.

22. Gadelha CAG, Costa LS. Saúde e desenvolvimento no Brasil: avanços e desafios. Rev Saúde Pública 2012; 46 Suppl 1:13-20.

23. Gadelha CAG, Maldonado JMSV. Complexo industrial da saúde: dinâmica de inovação no âmbito da saúde. In: Giovanella L, Escorel S, Lobato LVC, Noronha JC, Carvalho AI, organizadores. Políticas e sistema de saúde no Brasil. 2a Ed. Rio de Janeiro: Editora Fiocruz; 2014. p. 247-81.
24. Barbosa AF, Mendes RC, Sennes R. Avaliação da política industrial, tecnológica e de comércio exterior para o setor farmacêutico. São Paulo: Federação Brasileira da Indústria Farmacêutica; 2007. (Estudos Febrafarma, 13).

25. Ministério da Saúde. Mais saúde: direito de todos: 2008-2011. 2ạ Ed. Brasília: Ministério da Saúde; 2008.

26. Presidência da República. Decreto de 12 de maio de 2008. Cria, no âmbito do Ministério da Saúde, o Grupo Executivo do Complexo Industrial da Saúde - GECIS, e dá outras providências. Diário Oficial da União 2008; 13 mai.

27. Ministério da Saúde. 7a reunião do Grupo Executivo do Complexo da Saúde no PBM (GECIS). http: //u.saude.gov.br/images/pdf/2015/janeiro/20/ Apresentacao-Gecis-2014-VF---15-01-2014.pdf (accessed on Mar/2016).

28. Geremia F, Biachini C, Stallivieri F, Geremia DS. Adensamento tecnológico do sistema de saúde brasileiro: desafios para a política de compras governamentais. In: Costa LS, Bahia L, Gadelha CAG, organizadores. Saúde desenvolvimento e inovação. v. 2. Rio de Janeiro: CEPESC Editora; 2015. p. 301-25.

29. Ministério da Ciência e Tecnologia e Inovação. Ciência, tecnologia e inovação para o desenvolvimento nacional: plano de ação 2012-2015 (balanço das atividades estruturantes). Brasília: Ministério da Ciência e Tecnologia e Inovação; 2011.

30. Costa A, Szapiro M, Cassiolato JE. Análise da operação do instrumento de subvenção econômica à inovação no Brasil. In: Conferência Internacional LALICS 2013: Sistemas Nacionales de Innovación y Políticas de CTI para um Desarrollo Inclusivo y Sustentable. http://www.redesist.ie.ufrj.br/lalics/ papers/88_Analise_da_operacao_do_instrumento_ de_subvencao_economica_a_inovacao_no_Brasil. pdf (accessed on Jul/2015).

31. Financiadora de Estudos e Projetos. Inova Saúde. http://www.finep.gov.br/apoio-e-financiamen to-externa/programas-e-linhas/programas-inova/ inova-saude (accessed on Jul/2015)

32. Gomes R, Pimentel V, Lousada M, Pieroni JP. O novo cenário da concorrência na indústria farmacêutica brasileira. BNDES Setorial 2014; (39): 97-134.

33. Pinto JPM. Interação entre empresas e instituições de ciência e tecnologia no sistema farmacêutico de inovação brasileiro: estrutura, conteúdo e dinâmica [Doctoral Dissertation]. Rio de Janeiro: Instituto de Economia, Universidade Federal do Rio de Janeiro; 2010

34. Scheffer M, Vieira MF. Sistema de patentes: barreiras para a inovação e o acesso a medicamentos. In: Costa LS, Bahia L, Gadelha CAG, organizadores. Saúde, desenvolvimento e inovação. v. 1. Rio de Janeiro: CEPESC Editora; 2015. p. 233-66.

35. Sen A. Las teorías del desarrolho a princípios del siglo XXI. Cuadernos de Economía 1998; 17:73-100.

36. Weil DN. Accounting for the effect of health on economic growth. Cambridge: National Bureau of Economic Research; 2007. (NBER Working Paper, 11455). 
37. World Health Organization. Macroeconomics and health: investing in health for economic development. Geneva: World Health Organization; 2001.

38. Sutz J. Is there a role for innovations in health equity? In: Cassiolato JE, Soares MCC, editors. Health innovations systems, equity and development. Rio de Janeiro: e-papers; 2015. p. 87-106.

\section{Resumo}

A efetivação da saúde como um direito fundamental exige importante esforço, teórico e político, de articulação das dimensões econômicas e sociais, por vezes contraditórias, do desenvolvimento. Este trabalho indica a necessidade de um olhar sistêmico das políticas relacionadas à base produtiva e de inovação em saúde e à construção do Sistema Único de Saúde (SUS). Investiga as relações entre saúde, inovação e desenvolvimento, buscando mostrar e atualizar os determinantes políticos, econômicos e sociais da experiência brasileira recente relacionada ao Complexo Econômico-Industrial da Saúde (CEIS). Mostra como a agenda da inovação e da produção nacional em saúde ganhou centralidade no projeto de construção do SUS. O artigo procura, assim, articular questões inerentes à agenda do desenvolvimento, da produção e da inovação com a política social em saúde, tal como observado nos últimos anos e, valendo-se de sua análise, aponta desafios políticos e conceituais para a efetivação do SUS, em especial no que se refere ao fortalecimento de sua base tecnológica e produtiva. Como desdobramento, desenvolve um enfoque analítico e factual que relaciona a consolidação do CEIS no Brasil tanto como um vetor dinâmico do desenvolvimento industrial, gerando investimento, renda, emprego e inovações, quanto como elemento decisivo para a redução da vulnerabilidade e da dependência estrutural em saúde. Procura mostrar que seu fortalecimento e direcionamento para as necessidades sociais é parte essencial da construção de um Estado de Bem-Estar Social no Brasil.

Política Nacional de Ciência, Tecnologia e Inovação; Tecnologia Biomédica; Política Social; Desenvolvimento Sustentável; Inovação
39. Abrol D, Sundararaman T, Madhavan H, Joseph KJ. Building of health innovations systems. In: Cassiolato JE, Soares MCC, editors. Health innovations systems, equity and development. Rio de Janeiro: e-papers; 2015. p. 145-72.

40. Lundvall B-A. Preface. In: Cassiolato JE, Soares MCC, editors. Health innovations systems, equity and development. Rio de Janeiro: e-papers; 2015. p. 11-4.

\section{Resumen}

La consideración efectiva de la salud como un derecho fundamental exige un importante esfuerzo, teórico y político, de articulación entre las dimensiones económicas y sociales, a veces contradictorias, del desarrollo. Este trabajo expone la necesidad de una análisis sistémico de las políticas relacionadas con la base productiva y de innovación en salud y la construcción del Sistema Único de Salud (SUS). Investiga las relaciones entre salud, innovación y desarrollo, buscando mostrar y actualizar los determinantes políticos, económicos y sociales de la experiencia brasileña reciente, relacionada con el Complejo Económico-Industrial de la Salud (CEIS). Muestra de qué forma la agenda de innovación y producción nacional en salud ha conseguido ser el centro en el proyecto de construcción del SUS. El artículo busca, de esta forma, relacionar cuestiones inherentes a la agenda del desarrollo, de la producción e innovación en salud con la política social en salud, tal y como se ha observado en los últimos años y, valiéndose de su análisis, apuntar los desafíos políticos y conceptuales para los logros efectivos del SUS, en especial, en lo que se refiere al fortalecimiento de su base tecnológica y productiva. Como desdoblamiento, desarrolla un enfoque analítico y de hechos que relaciona la consolidación del CEIS en Brasil, tanto como un vector dinámico del desarrollo industrial, generando inversión, renta, empleo e innovación, así como elemento decisivo para la reducción de la vulnerabilidad $y$ de la dependencia estructural en salud. Procura mostrar que su fortalecimiento y direccionamiento hacia las necesidades sociales es parte esencial de la construcción de un Estado de Bienestar Social en Brasil.

Política Nacional de Ciencia, Tecnología e Innovación; Tecnología Biomédica; Política Social; Desarrollo Sostenible; Innovación
Recebido em 11/Set/2015

Versão final reapresentada em 04/Abr/2016 Aprovado em 05/Abr/2016 